\title{
Response of intertidal macrobenthic communities to long term human induced changes in the Eo estuary (Asturias, Spain): Implications for environmental management
}

\author{
L. de Paz ${ }^{\mathrm{a}, *}$, J.M. Neto ${ }^{\mathrm{b}}$, J.C. Marques ${ }^{\mathrm{b}}$, A.J. Laborda ${ }^{\mathrm{a}}$ \\ ${ }^{a}$ Department of Biodiversity and Environmental Management, Zoology Area, University of Leon, Campus de Vegazana, 24125 León, Spain \\ ${ }^{\mathrm{b}}$ IMAR - Institute of Marine Research, a/c Department of Zoology, Faculty of Sciences and Technology, University of Coimbra, 3004-517 Coimbra, Portugal
}

\section{A R T I C L E I N F O}

\section{Article history:}

Received 10 October 2007

Received in revised form 17 April 2008

Accepted 28 April 2008

\section{Keywords:}

Benthos

Long-term

Shellfish culture

Ecosystem disturbance

Environmental impact

Eo estuary

Cantabric sea

\begin{abstract}
A B S T R A C T
Long term macrobenthos data together with physical habitat parameters were analysed to investigate spatial and temporal changes at an estuary under different anthropogenic pressures, mainly increasing shellfish farming. The aim was to assess the possible impacts of these pressures on the macrobenthic communities by comparing a period before and after changes in these pressures. Benthic samples were seasonally collected in 1990 (before major anthropogenic changes), 2000 and 2005 at the same sampling stations located on three different habitats in the Eo estuary (Northern Spanish coast). Multivariate and univariate methods were used to assess spatial variability of benthic assemblages and to compare community changes over time. Data from 1990 was assumed as the reference situation to appraise the subsequent impacts.

We observed a significant spatial variability of the benthic assemblages in the system as a function of habitat heterogeneity in relation to sediment composition, presence/absence and density of seagrasses, and hydrodynamic regime. Changes were detected in the community composition at all sites during this 15 year period. The extent of changes was related to initial community conditions, rather than the intensity of the pressure. The results suggest that the responses of the benthic communities to human induced perturbations occurring in the system are largely dependent on its intrinsic buffer capacity, and that these communities have been able to cope with an increasing environmental stress (organic enrichment). In conclusion, to keep shellfish farming at a sustainable level without undesirable impacts, the disturbance intensity must be kept below the system carrying capacity. This will allow natural communities to cope with pressures and thus avoid further deterioration in ecological quality.
\end{abstract}

(c) 2008 Elsevier Ltd. All rights reserved.

\section{Introduction}

The estuarine faunal composition may show considerable variation, over spatial scales from metres to kilometres, and temporal scales of days to years (Morrisey et al., 1992a, b). Such variations in diversity or abundance of benthos in estuarine systems have been often correlated with environmental variables (e.g. salinity; Sanders et al., 1965; tidal level; Warwick and Uncles, 1980; sediment characteristics; Gray, 1974; Chapman and Tolhurst, 2004), density of seagrass plants (e.g. Boström and Bonsdorff, 1997), biotic interactions (e.g. Wilson, 1991), or perturbations (e.g. Pearson and Rosenberg, 1978; Llansó, 1992; Diaz and Rosenberg, 1995; Belan, 2003). Therefore, the estuarine community structure can change as a continuum on various spatial and temporal scales in relation to both natural and anthropogenic gradients (Pearson and Rosenberg, 1978; Rakocinski et al., 1997). Sampling can capture only a

\footnotetext{
* Corresponding author. Tel.: +34 987291515; fax: +34 987291855.

E-mail address: lpazl@unileon.es (L. de Paz).
}

segment of a community at temporally or spatially discrete intervals, often missing critical transition points in between, and it may become difficult to establish causal relationships between stressors and effects on marine resources. Long-term surveys are a useful tool to assess changes in marine ecosystems, because they characterize environments and provide a basis to understand temporal and spatial variations in community structure and natural sources of stress that might mask a response to anthropogenic disturbance.

In recent years, aquaculture production has increased worldwide, as well as the need of assessing its environmental effects. Although depositional effects from shellfish farming culture can be negligible (e.g., Crawford et al., 2003; Grant et al., 1995), most studies describe a degree of sediment enrichment beneath culture areas and an alteration in the benthic community (Castel et al., 1989; Hartstein and Rowden, 2004; Forrest and Creese, 2006). However, additional impacts, related to intertidal culture, have also been observed, such as topographic changes resulting from altered patterns of sediment accretion or erosion (e.g., Ottmann 
and Sornin, 1982; Everett et al., 1995), accumulation of shell litter, destruction of seagrasses beds, and physical disturbance from operational activities. The increase in shellfish culture, mainly oyster culture, in estuarine intertidal areas around the world, and the high economic and ecologic importance of estuaries, requires a more intensive survey of the impacts of this activity on benthic habitats and communities.

The Eo estuary, located in the north coast of Spain, has been a centre of bivalve farming since the 1970s (Guerra et al., 1987). Shellfish are off-bottom cultivated, in culture bags placed onto racks. In the first years, the main species cultivated was Ostrea edulis, but since 1978 this oyster culture collapsed due to infestation by Bonamia ostreae, a parasite from California, which caused severe mortalities (Carrasco and Rodríguez, 1990). In late 1980s and early 1990s, shellfish farming in the estuary received a new impulse with the introduction of the Pacific oyster (Crassostrea gigas) and manila clam (Ruditapes philippinarum) (Cigarría et al., 1995). A total area of $0.56 \mathrm{~km}^{2}$ was retained for shellfish farming within an inlet located in the eastern side of the estuary (Linera inlet), representing $37 \%$ of the whole inlet area. Since 2000 all the farming area has been occupied with oyster racks. The production was estimated at 185 tonnes in 2001, increasing to 368 tonnes in 2004, and since then has become stabilized at approximately 300 tonnes per year. Recently, new plans aiming at increasing the bivalve production to 400 tonnes per year have been developed.

In addition to the development of oyster farming, the building of a new harbour in the western part of the estuary in 1994 created an additional human pressure. Although we do not have data on currents, it might have induced changes in hydrodynamics, which may have caused the observed increase in sand deposition in the navigation channels. Furthermore, it has probably been necessary to increase the frequency of dredging activities to maintain the main navigation channels operational, but we do not have quantitative data on this activity.

To evaluate the possible impacts resulting from these anthropogenic pressures on the Eo estuary macrobenthic communities, we examined the spatial and temporal changes in the system response before and after the introduction of intensive shellfish farming and the harbour construction and operation (Hill et al, 1999). An intensive survey of the intertidal benthic fauna was carried out in 1990 at the outer part of the Eo estuary (Laborda and Cimas, 1991; Laborda, 1995), and the results from that study were considered as representing a reference situation prior to the observed changes. Subsequently, in 2000 and 2005, only the most representative sampling stations utilised in 1990 sampling were re-sampled. The results from the three sampling campaigns were compared with three main objectives:

(i) To determine the extent to which the Eo estuary macrobenthic communities have changed over the last 15 years.

(ii) To characterize such changes relating it to the system's physical conditions.

(iii) To assess to what extent these changes occurred as a response to increasing human pressures, with emphasis on oyster farming.

\section{Material and methods}

\subsection{Study area}

The Eo estuary is a shallow mesotidal system (tidal range $=1.20-4.80 \mathrm{~m}$ ) located on the northern Cantabric coast of

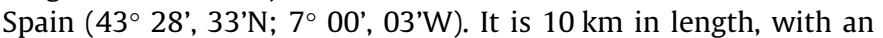
average width of $800 \mathrm{~m}$, and a total area of $9.6 \mathrm{~km}^{2}$. Depth varies between 2 and $7 \mathrm{~m}$, and the intertidal area represents approximately $83 \%$ of the total estuarine area. According to the Water
Framework Directive (WFD) typology established for the Basque Country (Spain) (Borja et al. 2004), the Eo estuary is classified as type TWII. This type includes mesotidal (tidal range 1-3 m) polyhaline-euhaline estuaries with extensive intertidal areas and permanent stratification.

Sampling stations (Fig. 1) were located in the outer part of the estuary, which comprised two sectors: (a) a sheltered inlet, the Linera inlet, at the eastern side of the Estuary; and (b) a sand bare area consisting of sand banks in the main channel.

The Linera inlet has an area of $1.5 \mathrm{~km}^{2}$ and represents a largely flat bottom mainly covered by Zostera noltii and Zostera marina seagrass beds. Z. noltii occurs on muddy bottoms, at higher tidal levels, in the inner parts of the inlet, while a mixed meadow consisting of $Z$. noltii and $Z$. marina is present on sandy-mud bottoms from lower tidal levels, closer to the inlet's mouth.

The shape of the sand banks has been changing continuously and their extension increased over time (Encinar and Rodríguez, 1983). Similar to other estuaries from the northern coast of Spain (Curras and Mora, 1991), the Eo is undergoing a gradual process of in-filling with marine and estuarine deposits.

In both sectors, salinity close to the bottom usually ranges from 34 to $36 \mathrm{ppt}$

\subsection{Reference situation (Laborda and Cimas, 1991; Laborda, 1995)}

The analysis of 100 samples collected in 1990 (25 randomly selected sampling stations were seasonally sampled) allowed the characterization of three different habitat types based on sediment's granulometry, organic matter content, presence of seagrasses, and macrobenthic communities' distribution (Table 1) (Laborda and Cimas, 1991; Laborda, 1995; Laborda et al. 1997).

Within each habitat type, different zones were identifiable (Table 1):

- Three different zones within the bare sediment (BS) habitat (Fig. 1 ), which may be explained as a function of hydrodynamic conditions (Table 1).

- Four different zones within the apparently homogeneous habitat of mudflats covered by Z. noltii (MZ) (Fig. 1), explainable as a function of spatial variations in the density of seagrass shoots (Table 1).

- Two slightly different zones were recognized within the mixed Z. noltii and Z. marina meadows (SMZ) (Fig. 1), which may be explained by differences in sediments composition (Table 1 ).

\subsection{Sampling programme and laboratory procedures}

In 2000 and 2005, 9 sampling stations were selected as representative of the different habitats and zones previously characterized, coinciding with points sampled in the 1990 survey (Laborda and Cimas, 1991; Laborda, 1995) (Fig. 1). Samples were seasonally collected during low spring tides, in February (winter), May (spring), August (summer) and October (autumn).

Sampling procedures were nevertheless different from the 1990 campaigns. In fact, in 1990, following a common procedure at that time (e.g. Junoy and Viéitez, 1990), a minimum representative area of $0.16 \mathrm{~m}^{2}$ and $0.40 \mathrm{~m}$ in depth was selected, and single samples were taken at each one of the sampling stations. On the contrary, in 2000 and 2005 samples consisted of eight replicates of $0.0123 \mathrm{~m}^{2}$ and $0.2 \mathrm{~m}$ in depth, collected with a manual corer, which was considered enough to stabilize spatial variability (Frontier, 1983). It was therefore necessary to legitimize the comparison of the different data sets. A test comparing two sets of samples collected at five stations using both sampling strategies, carried out in 2005 , showed that differences regarding the number of species and 


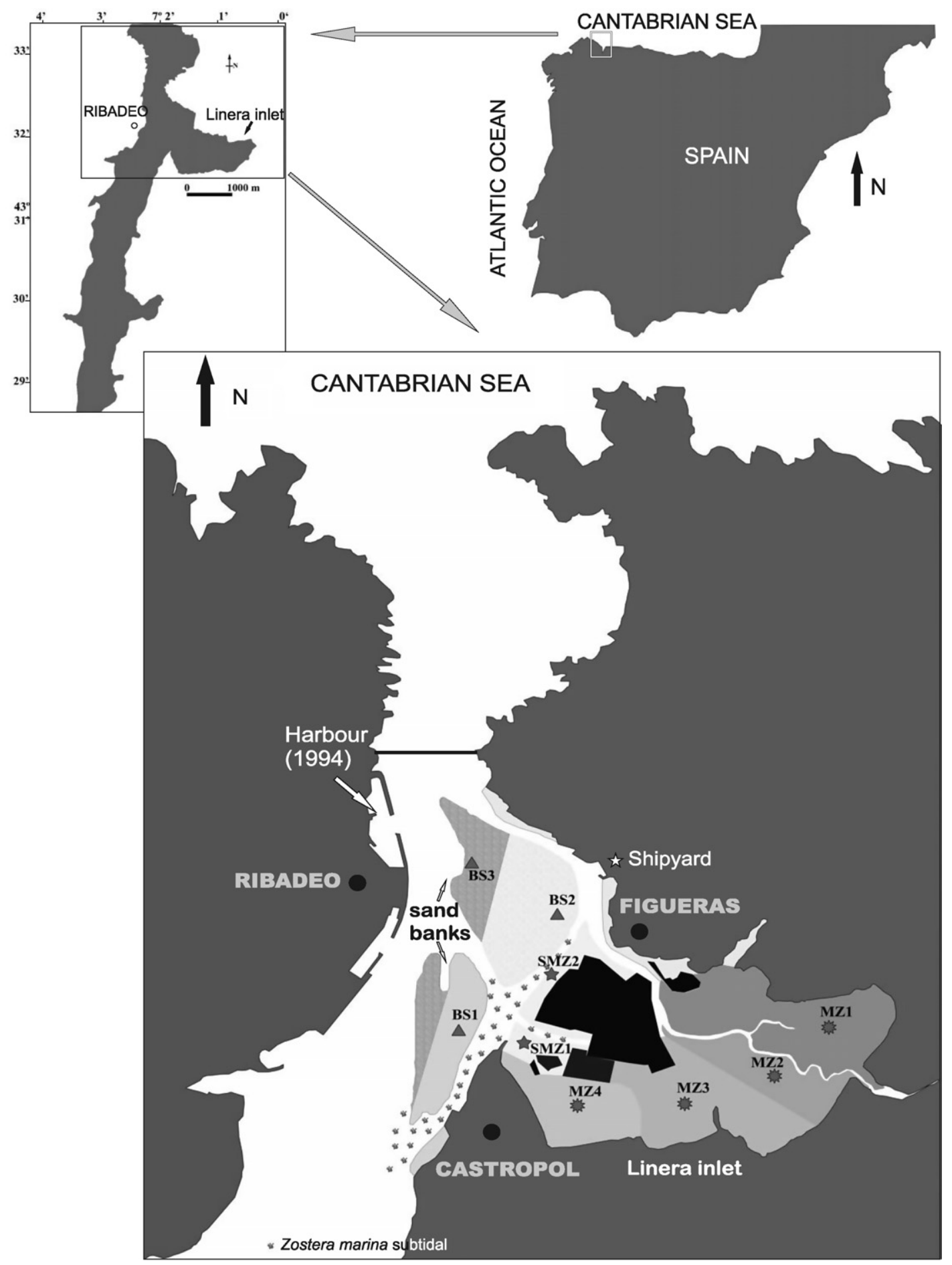

Fig. 1. Terminal part of Eo estuary, showing sampling areas and location of oyster farms (black areas).

their abundances were not significant (nMDS plot Fig. 2; ANOSIM test: $R=-0.125, p=0.77$ ).

In all cases, samples were sieved in situ through a $0.5 \mathrm{~mm}$ calibrated mesh size bag and preserved in $4 \%$ buffered formalin. In the laboratory, after sorting, invertebrates were identified to the species level, whenever possible, counted and stocked in $70 \%$ alcohol. Organisms' biomass was determined as ash free dry weight (AFDW) after oven drying at $60^{\circ} \mathrm{C}$ for $72 \mathrm{~h}$ and combustion at $450{ }^{\circ} \mathrm{C}$ for $8 \mathrm{~h}$.

Together with biological sampling, salinity, temperature and dissolved oxygen were measured in situ from water retained in intertidal water pools. Additionally, sediment samples were collected for laboratory analysis of organic matter content and granulometry. The organic matter content was determined by loss on ignition $\left(24 \mathrm{~h}\right.$ at $\left.450{ }^{\circ} \mathrm{C}\right)$, and the sediment particles size fractions were determined following a standard mechanic sieving procedure (Buchanan, 1984) and classified according to the Wentworth scale: gravel $(\emptyset>2 \mathrm{~mm})$, very coarse sand $(2 \mathrm{~mm}>$ $\emptyset>1 \mathrm{~mm})$, coarse sand $(1 \mathrm{~mm}>\emptyset>0.5 \mathrm{~mm})$, medium sand $(0.500 \mathrm{~mm}>\emptyset>0.250 \mathrm{~mm})$, fine sand $(0.250 \mathrm{~mm}>\emptyset>0.125 \mathrm{~mm})$, very fine sand $(0.125 \mathrm{~mm}>\varnothing>0.062 \mathrm{~mm})$, and silt $(\varnothing<$ $0.062 \mathrm{~mm}$ ). 
Table 1

Description of the reference situation

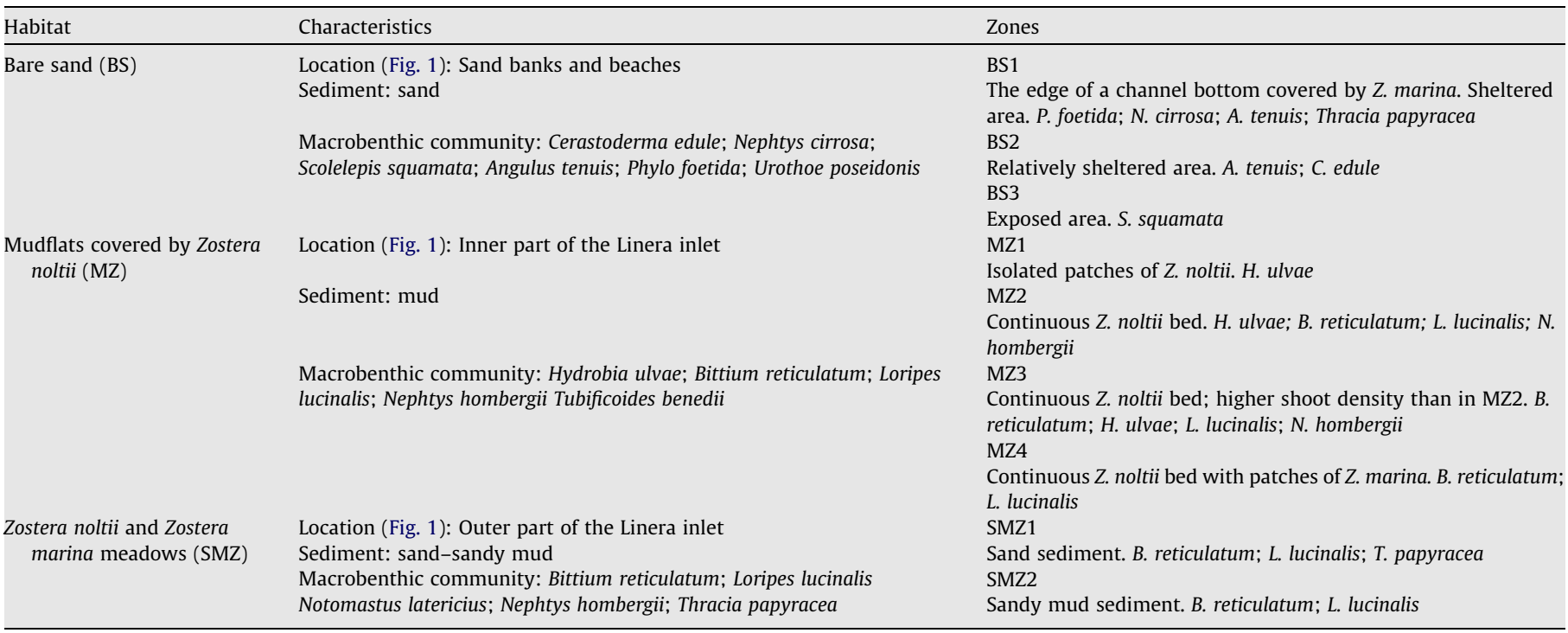

Also, the area occupied by the different habitats at the different years was calculated using GPS field data and through the analysis of aerial and satellite photographs (with OziExplorer GPS mapping software and ArcGIS software).

\subsection{Data analysis}

Spatial and inter-annual variations of the Eo estuary benthic communities were assessed through the application of multivariate statistical techniques and ecological indicators.

Multivariate analysis of both physicochemical and biological data was performed by using the PRIMER software package (Clarke and Warwick, 2001; Clarke and Gorley, 2001). Regarding data on benthic macrofauna species abundance $\left(\right.$ ind $\mathrm{m}^{-2}$ ), a similarity matrix was calculated using the Bray-Curtis coefficient after a four root transformation. Benthic assemblages were examined using a non-parametric multidimensional scaling ( $\mathrm{n}$-MDS) ordination. In addition, differences in species abundance among different habitats and years were analysed through a similarity test (ANOSIM), a non-parametric procedure analogous to ANOVA. The relative contribution of each species to average similarities between years

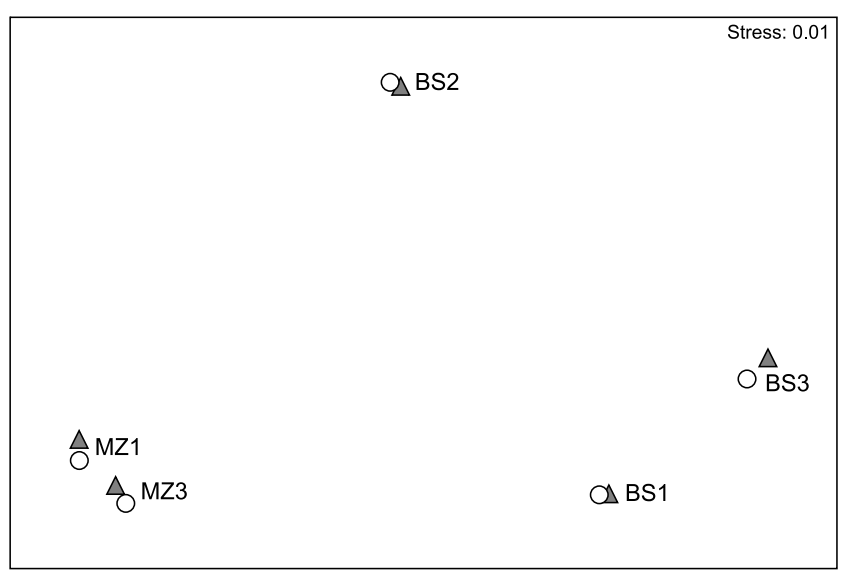

Fig. 2. Non-metric MDS plot of faunal density data comparing the two sampling procedures. Grey triangles represent corer samples and white circles represent spade samples. was estimated applying SIMPER analysis. Finally, relationships between benthic distributional patterns and physicochemical variables were analysed through the BIOENV (biological environmental gradients) procedure.

Data were also analysed to estimate several ecological indicators: total abundance (ind $\mathrm{m}^{-2}$ ) $(N)$, total species richness $(S)$, Margalef index $(d)$, Pielou evenness index $\left(J^{\prime}\right)$, Shannon-Wiener, $\log _{2}$ $\left(H^{\prime}\right), W$-statistic index (Clarke, 1990), based on the ABC method proposed by Warwick (1986), and the AZTI marine biotic index (AMBI) (Borja et al., 2000). AMBI was computed using AMBI@ software (Borja et al., 2003), which is freely available at http:// www.azti.es.

The statistical significance of temporal differences observed between the chosen indices was further examined using one-way ANOVA. Data were transformed prior to analysis with a double square root transformation in order to improve homoscedasticity. Post hoc Tukey tests were employed to identify sampling dates differing significantly. These statistical analyses were performed with the SPSS software package.

\section{Results}

A total of 53949 individuals belonging to 289 macrobenthic taxa were identified from the samples collected in 1990, 2000, and 2005 . Only 84 species (29\%) were found in all the campaigns, while $44(15 \%)$ were collected exclusively in 1990, 27 (9\%) in 2000 , and $52(18 \%)$ in 2005.

\subsection{Habitat parameters}

The estuarine intertidal area increased over the study period (from 193 ha in 1990 to 212 ha in 2005), especially the bare sand areas (from 53 ha in 1990 to 70 ha in 2005). On the other hand, it was observed an important reduction in the extension of the Zostera seagrass beds, namely of the mixed Z.noltii-Z. marina meadow (from 40 ha in 1990 to 8 ha in 2005). This is actually the area where most of the culture racks have been installed, and before putting them in place seagrasses were directly removed from the site, leaving the sediments beneath the farms without vegetation.

Results for sediment particle size are showed in Fig. 3. Only the relative percentages of the main fractions have been presented, which were medium, fine and very fine sand, and silt. With the 
exception of MZ1, a gradual increase in the proportion of fine sediments was observed in all samples from 1990 to 2005. Similarly, the percentage of organic matter in the sediment increased in all zones, with the exception of station MZ1 (Fig. 4). The strongest increase was found in the stations of $Z$. noltii- $Z$. marina mixed meadows.

\subsection{Spatial structure and temporal changes in macrobenthic communities}

Stations located at bare sandy bottoms, mudflats covered by $Z$. noltii, and Z. noltii-Z. marina mixed meadows on sandy and sandy-muddy sediments are clearly differentiated in the nMDS analysis (Fig. 5), ranging along a gradient from the inner part of the Linera inlet to the sand banks. ANOSIM shows that there are significant differences in the macrofauna community composition among different habitats $(R=0.547, p<0.01)$, especially between mudflats with Z. noltii (MZ) and bare sand areas (BS) $(R=0.717$, $p<0.01$ ). The $Z$. noltii-Z. marina mixed meadows (SMZ) appear to have intermediate characteristics, as compared to $\mathrm{MZ}(R=0.391$, $p<0.01)$ and BS $(R=0.369, p<0.01)$. Differences between habitats were therefore obvious, confirming results previously obtained (Laborda and Cimas, 1991; Laborda, 1995), although a few sampling stations might have exhibited intermediate characteristics.

In general, BIOENV results, for all samples, show weak correlations between fourth-root transformed sediment physicochemical parameters and macrobenthos abundances. Correlations were nevertheless comparatively stronger with very fine sand and silt fractions $(r=0.353)$. Besides, correlations were also higher when different years were analysed separately. In 1990, macrobenthic abundances exhibited the highest correlation with the very fine sand fraction $(r=0.643)$, in 2000 with all the fine fractions (fine sand to silt) and organic matter content $(r=0.604)$, and in 2005 with the silt fraction $(r=0.669)$. This suggests that sediment variables, although important, might not be sufficient to explain inter-annual variability.

The nMDS plot comparing two sets of samples collected at five stations using both sampling strategies (Fig. 2), shows that the results obtained from different sampling procedures were very similar. Once established that different sampling strategies would not introduce significant changes in results (ANOSIM; $R=-0.125$, $p=0.77$ ), samples from different years were compared.

Spatial changes due to differences between habitats, as well as seasonal variations, if all the samples were considered together,

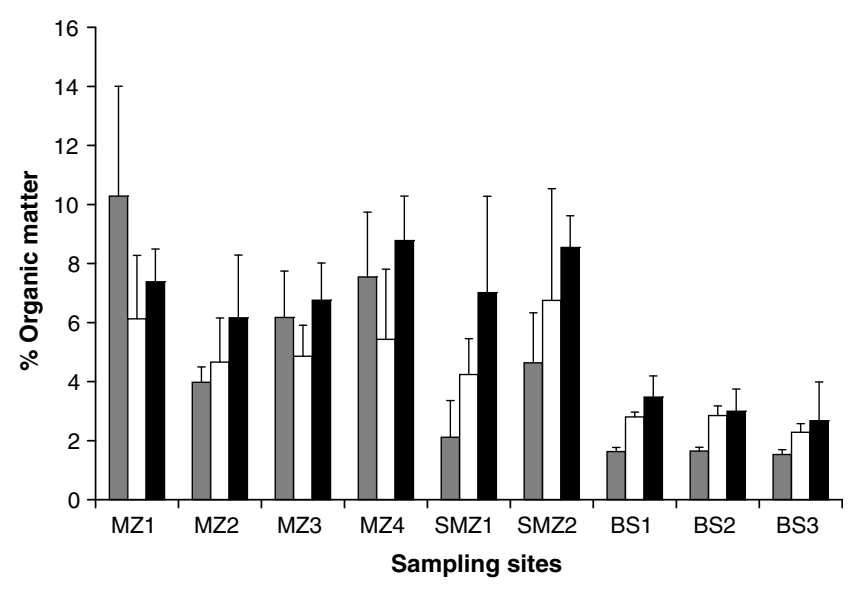

Fig. 4. Percentage of sedimentary organic matter content (mean + s.d.). Grey bars represent 1990 samples, clear bars represent 2000 samples and black bars represent 2005 samples.

could make the analysis of inter-annual changes complex. Therefore, inter-annual changes taking place at different types of habitat were analysed separately for each season. Regarding the Z. marinaZ. noltii mixed meadow, stations MZ4 and BS1, which in 1990 presented transitional characteristics, were also included in the analysis. This allowed us to examine whether these stations maintained their intermediate characteristics, or became more similar to any of the nearby habitats.

The nMDS ordination analysis (Fig. 6) shows a comparable seasonal pattern of organisation between different years. In general, samples from 1990 and 2005 tended to form distinct groups, while samples from 2000 appear more dispersed in the projection. Nevertheless, this pattern was not so clear regarding samples from the bare sand habitat, which was due to a lower similarity between different stations, even within the same year.

Taking into account the whole set of samples, ANOSIM did not reveal significant differences between years $(R=0.1, p<0.01)$, but differences became clearly higher when each habitat was considered separately. In fact, significant differences in species composition between years were found for both the MZ and SMZ zones $(R=0.435, p<0.001$, zone MZ; $R=0.588, p<0.01$, zone SMZ), which is particularly evident in the case of samples from 1990

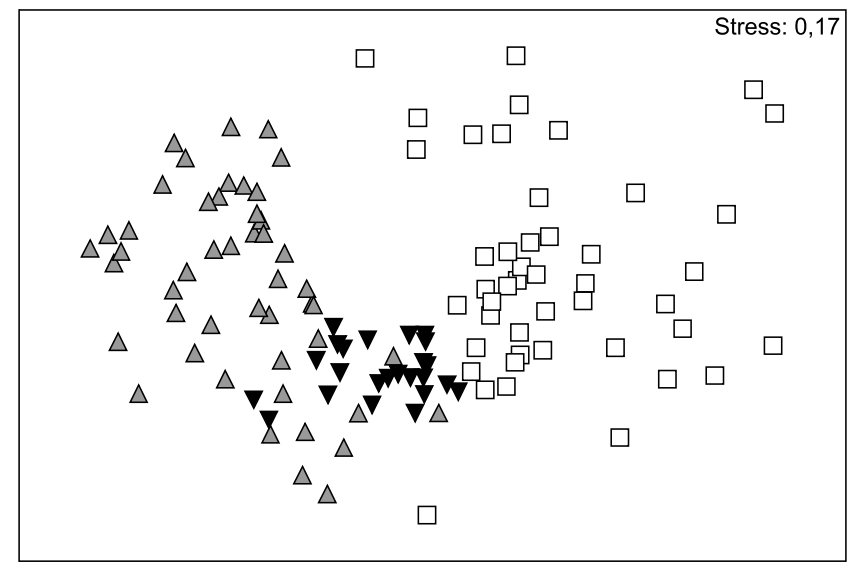

Fig. 5. Non-metric MDS plots of benthic community structure at 9 stations sampled in Eo estuary in Febrary, May, August, October of 1990, 2000 and 2005. Grey triangles represent mud flat covered by $Z$. noltii samples ( $\mathrm{MZ}$ area), black triangles represent $Z$. marina and $Z$. noltii mixed meadow samples (SMZ area) and empty squares represent bare sand samples (BS area).
Fig. 3. Relative percentages of medium sand (white), fine sand (clear grey), very

fine sand (dark grey) and silt (black). From left to right 1990, 2000 and 2005

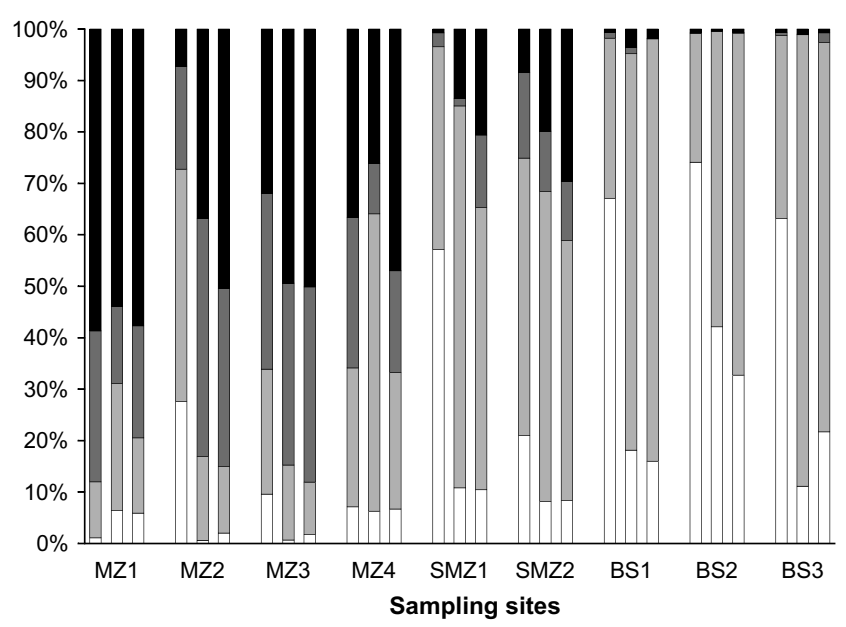


and $2005(R=0.702, p<0.01$, zone MZ; $R=0.861, p<0.01$, zone SMZ). Regarding the bare sand habitat stations, ANOSIM did not show significant inter-annual differences $(R=0.137, p=0.003)$, probably because of the great spatial variability in this zone.

\subsection{Variation in species composition}

Species contributing the most to the observed inter-annual differences in community structure were identified applying SIMPER to calculate their relative contributions to the overall average dissimilarity (Table 2).

In the mud flats covered by $Z$. noltii and in the Z. noltii-Z. marina mixed meadows, with the exception of $B$. reticulatum and $L$. lucinalis, all the species primarily responsible for inter-annual differences, increased in abundance in 2000, and again, even more, in 2005 (Table 2).
In the bare sand areas, the species that contributed the most to inter-annual variations (Table 2), exhibited strong seasonal variability, namely in 2005. As a trend, the average abundance of polychaetes increased from 1990 to 2000, decreasing in 2005. On the other hand, bivalves suffered a decrease both in number of species and average abundance from 1990 to 2000 and although densities recovered after 2000 , it was observed a reduction in the size of individuals. Finally, the crustaceans' average abundance increased from 1990 to 2000, suffering a reduction in 2005. Indeed, most of the seasonal and inter-annual variations observed in this habitat were due to isolated species.

\subsection{Ecological indicators}

Values of the ecological indicators seasonally estimated for the different habitats during the study period are shown in Fig. 7. With
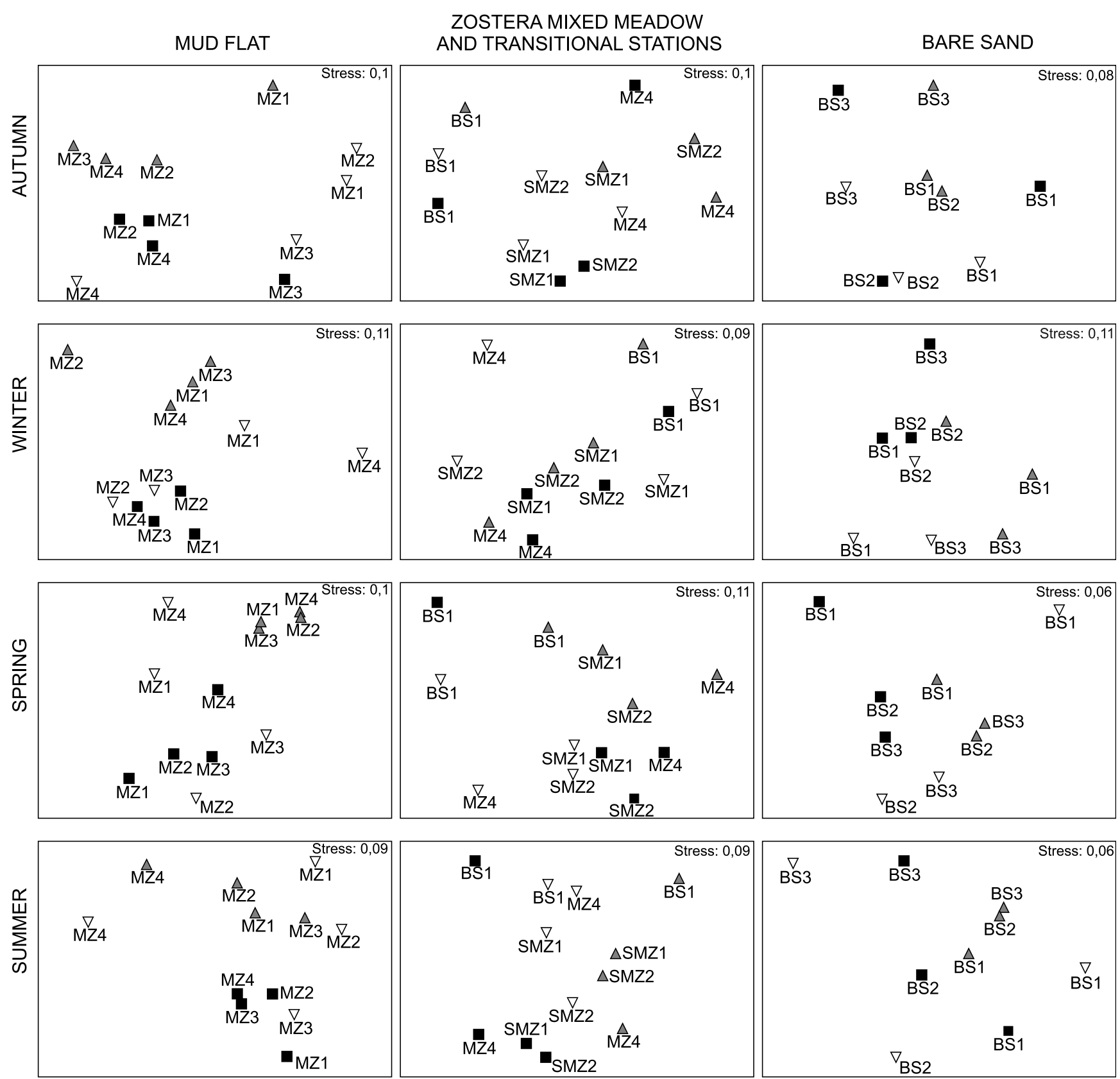

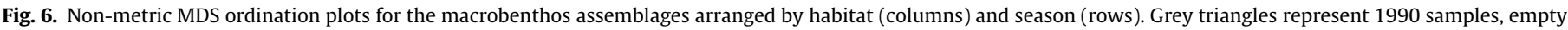
inverse triangles represent 2000 samples and black squares represent 2005 samples. 
the exception of AMBI, all indices showed a strong seasonal variability which makes it difficult to interpret inter-annual variations (Fig. 7). Actually, these results are consistent with the findings of Reiss and Kroncke (2005), who demonstrated that univariate indices show higher seasonal variability than multimetric indices such as AMBI. In general, if an index shows higher/lower values than in a previous campaign, at least in three of the four seasons, we assumed that it increased/decreased in that station during that year.

Independently of the year, values of the chosen indices showed a strong variability between the different zones. The SMZ zone presented the highest values in terms of species richness and other diversity measures, while the BS zone showed the highest values of $W$-statistic and Pielou evenness. On the other hand, the maximum values of AMBI were always found in the MZ zone (Table 3).

Values of the different indices are consistent with results regarding the macrobenthic community structure, illustrating the intermediate characteristics of transitional stations between the different zones. In fact, in the MZ zone, station MZ4 showed the highest values regarding species richness and diversity indices, analogous to those obtained in the SMZ zone, and in the BS zone the highest diversity measures were found at the BS1 station (Fig. 7).

In 1990, despite the fact that this year was assumed as the reference situation, the mudflat stations showed relatively high AMBI values, especially at the MZ1 station (Fig. 4). Nevertheless, at all stations and in every season, AMBI values were higher in 2000, and even more in 2005. Therefore, there was an apparent degradation of the macrobenthic community at the different habitats from the 1990s' until the present. This degradation is also illustrated by the diversity indices and the $W$-statistic index both at the sandy stations and at stations with larger cover of Z. noltii (MZ2 and MZ3). Nevertheless, with regard to the SMZ zone and MZ1 and MZ4 stations, we found some inconsistencies between the assessments provided by AMBI, the $W$-statistic, and the other indices. In fact, according to the diversity indices the ecological quality of these stations appears to have improved in 2005 as compared to the reference situation (Table 3), while AMBI values suggest the contrary. Actually, the species number and abundance increased at these zones in 2005, especially at SMZ zone, but most of these species were opportunists or indicators of organic enrichment. Consequently, despite the increase in diversity values, AMBI showed a deterioration of the system throughout time. On the other hand, at the SMZ, the $W$-statistic values were higher in 2000 than in 1990 and 2005, indicating a possible disturbance situation in those years. The Pielou index provides a similar picture, showing an improvement at the SMZ zone between 1990 and 2000. Nevertheless, the variation in the values of these two indices was not statistically significant (see Table 4).

One way ANOVA, taking into account the values of the different indices, showed that the mean values were significantly different between sampling years, with the exception of the $W$-statistic and Pielou evenness (Table 4 ). The Tukey's test showed a statistically significant decrease $(p<0.05)$ in the values of the Margalef and Shannon-Wiener between 1990 and 2000, and a concomitant increase in the values of AMBI and abundance $(p<0.001)$. On the other hand, in 2005, abundance increased significantly $(p<0.005)$ as compared to both 1990 (the reference situation) and 2000, while the number of species increased significantly only in relation to $2000(p<0.005)$, and AMBI showed a significant $(p<0.001)$ increase in comparison to the reference situation.

Table 2

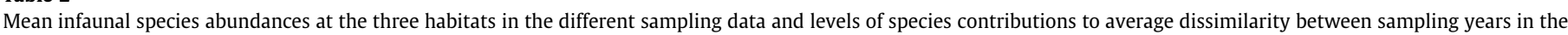
different zones

\begin{tabular}{|c|c|c|c|c|c|c|}
\hline & 1990 & 2000 & 2005 & Diss. $1990-2000$ & Diss. $1990-2005$ & Diss. 2000-2005 \\
\hline \multicolumn{7}{|l|}{ Mud flats covered by Z. noltii } \\
\hline Hydrobia ulvae & 346 & 5317 & 9439 & 1.38 & 1.50 & 1.36 \\
\hline Oligochaeta spp. & 0 & 47 & 839 & 0.64 & 1.88 & 1.43 \\
\hline Streblospio benedicti & 0 & 25 & 181 & 0.69 & 1.75 & 1.33 \\
\hline Capitella capitata & 1 & 11 & 448 & 0.53 & 1.52 & 1.33 \\
\hline Scrobicularia plana & 2 & 11 & 72 & 0.84 & 1.94 & 1.30 \\
\hline Cerastoderma edule & 2 & 9 & 66 & 0.77 & 1.30 & 1.19 \\
\hline Idotea balthica & 0 & 7 & 96 & 0.45 & 1.21 & 1.17 \\
\hline Bittium reticulatum & 248 & 3 & 263 & 1.50 & 1.30 & 1.32 \\
\hline Nephtys hombergii & 29 & 63 & 95 & 0.96 & 1.19 & 1.18 \\
\hline Loripes lucinalis & 366 & 40 & 73 & 1.23 & 1.23 & 1.20 \\
\hline Tubificoides benedii & 27 & 17 & 210 & 1.00 & 1.13 & 1.03 \\
\hline \multicolumn{7}{|c|}{ Mixed Z. marina-Z. noltii seagrasses bed } \\
\hline Pseudopolydora antennata & 12 & 186 & 1716 & 1.51 & 1.98 & 1.40 \\
\hline Capitella capitata & 17 & 80 & 1088 & 1.30 & 2.01 & 1.47 \\
\hline Tubificoides benedii & 3 & 10 & 1285 & 1.17 & 1.66 & 1.61 \\
\hline Oligochaeta spp. & 0 & 8 & 141 & 0.37 & 1.13 & 1.59 \\
\hline Exogone naidina & 14 & 1 & 629 & 0.68 & 2.16 & 2.94 \\
\hline Tanais dulongii & 41 & 150 & 897 & 1.10 & 1.78 & 1.52 \\
\hline Bittium reticulatum & 567 & 4 & 478 & 2.30 & 1.62 & 1.31 \\
\hline Euclymene oerstedii & 25 & 87 & 199 & 1.71 & 1.97 & 1.16 \\
\hline Nemertina & 1 & 57 & 213 & 2.76 & 3.40 & 1.63 \\
\hline Leiochone clypeata & 5 & 62 & 265 & 1.34 & 1.37 & 1.33 \\
\hline Mysella bidentata & 5 & 64 & 160 & 1.39 & 1.72 & 1.30 \\
\hline Microspio mecznikowianus & 6 & 20 & 346 & 0.83 & 1.77 & 1.53 \\
\hline Apseudes latreillei & 26 & 155 & 722 & 1.24 & 1.10 & 1.27 \\
\hline Iphinoe trispinosa & 33 & 14 & 172 & 1.17 & 1.28 & 1.21 \\
\hline \multicolumn{7}{|l|}{ Bare sand } \\
\hline Angulus tenuis & 17 & 32 & 109 & 1.23 & 1.16 & 1.13 \\
\hline Apseudes latreillei & 4 & 173 & 130 & 1.16 & 1.07 & 1.18 \\
\hline Scolelepis squamata & 13 & 90 & 17 & 1.00 & 1.00 & 0.89 \\
\hline Spio filicornis & 2 & 38 & 23 & 0.95 & 0.77 & 0.87 \\
\hline Urothoe poseidonis & 13 & 26 & 53 & 0.99 & 1.19 & 0.93 \\
\hline Nephtys cirrosa & 13 & 64 & 41 & 1.13 & 1.05 & 0.94 \\
\hline Thracia papyracea & 15 & 3 & 121 & 1.17 & 1.46 & 0.88 \\
\hline Cerastoderma edule & 14 & 10 & 117 & 0.99 & 0.90 & 0.60 \\
\hline
\end{tabular}



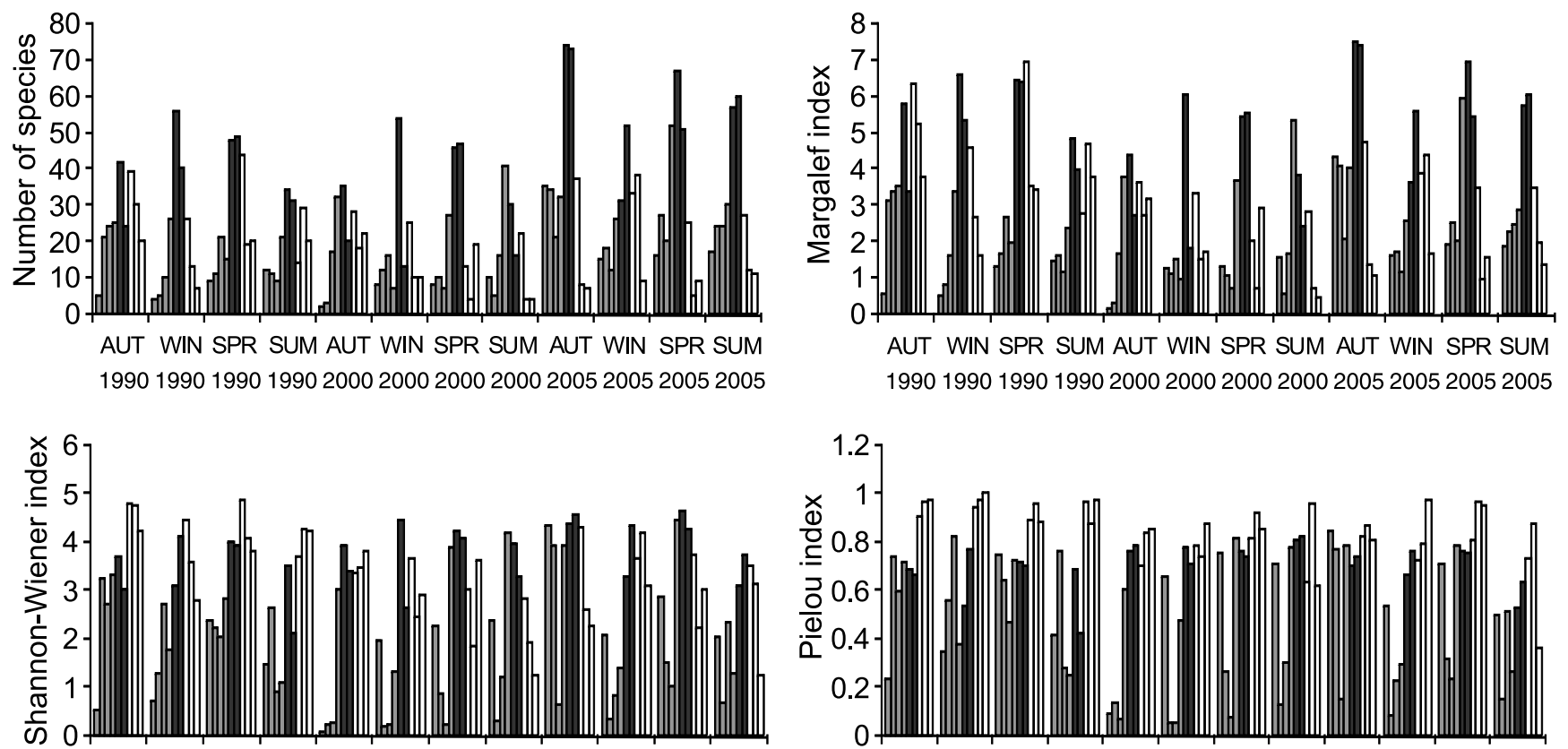

AUT WIN SPR SUM AUT WIN SPR SUM AUT WIN SPR SUM 199019901990199020002000200020002005200520052005

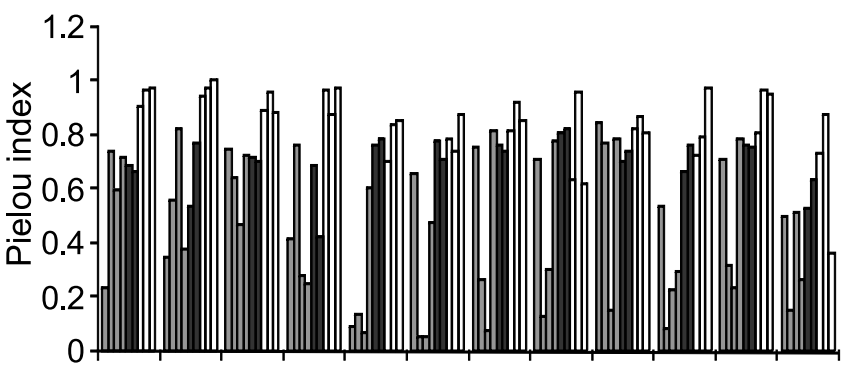

AUT WIN SPR SUM AUT WIN SPR SUM AUT WIN SPR SUM 199019901990199020002000200020002005200520052005
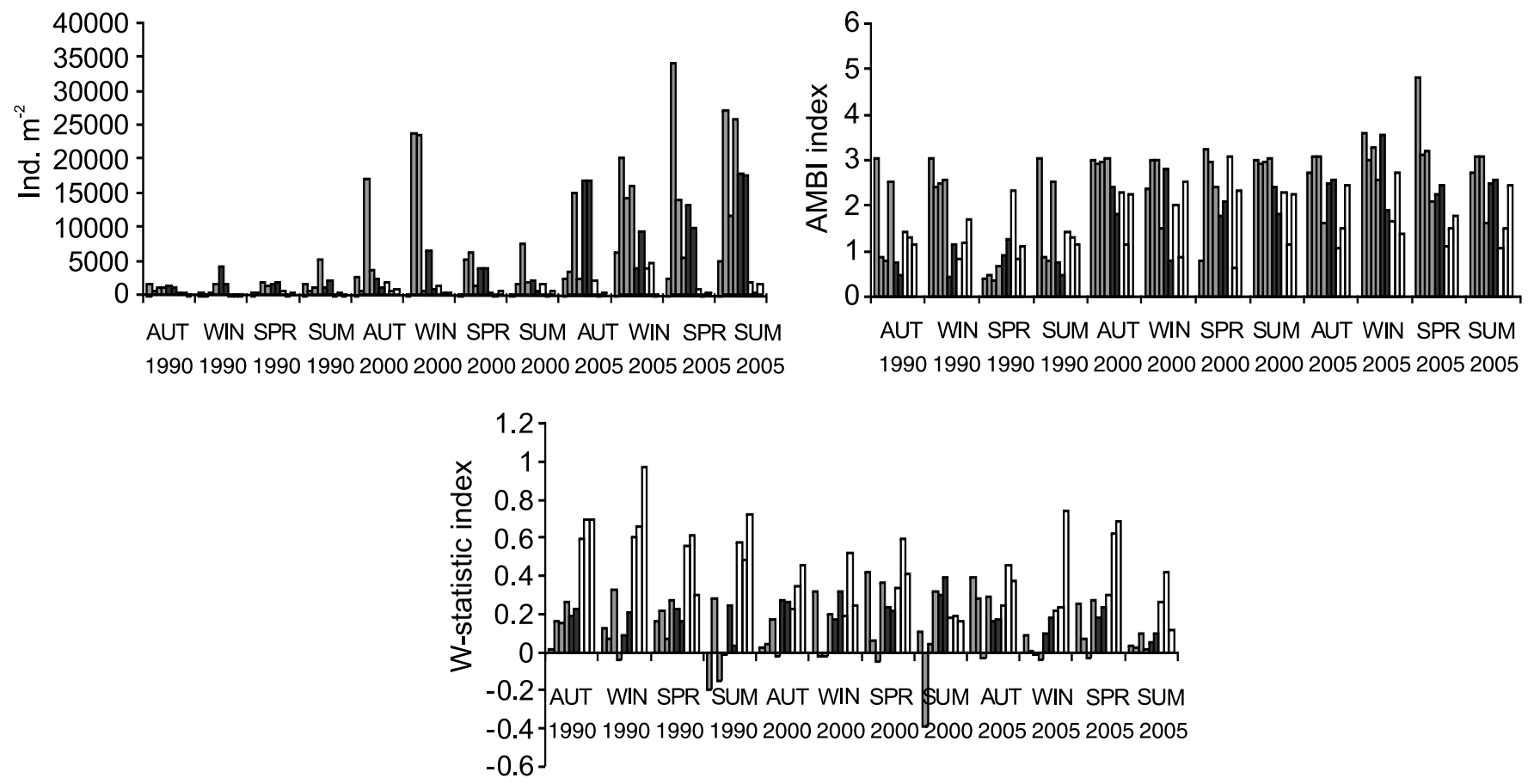

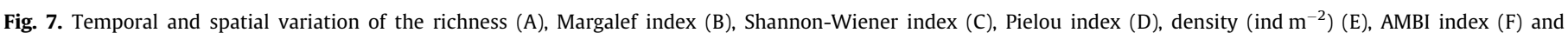

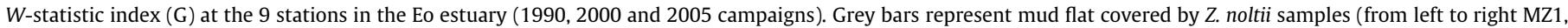

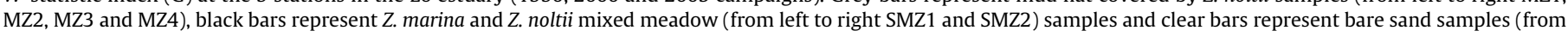
left to right BS1, BS2 and BS3).

In general, taking into account the mean values for each habitat values, all the selected indices suggest a worsening in the system between 1990 and 2000. Afterwards, the diversity indices express a slight recovery of the macrobenthic community in 2005 in comparison to 2000, while AMBI, on the contrary, suggests that degradation continued. Similarly, regarding the SMZ and $\mathrm{MZ}$ zones, diversity indices showed an improvement on the macrobenthic communities in 2005 as compared to the reference situation, while AMBI, the $W$-statistic and Pielou indices showed aggravation. Finally, all the indices showed degradation of the macrobenthic communities in the bare sand zone from 1990 to 2005.

\section{Discussion}

4.1. How have macrobenthic communities been changing in the Eo estuary?

The spatial patterns of distribution of individuals from shallowwater benthic species are reported to be largely controlled by 


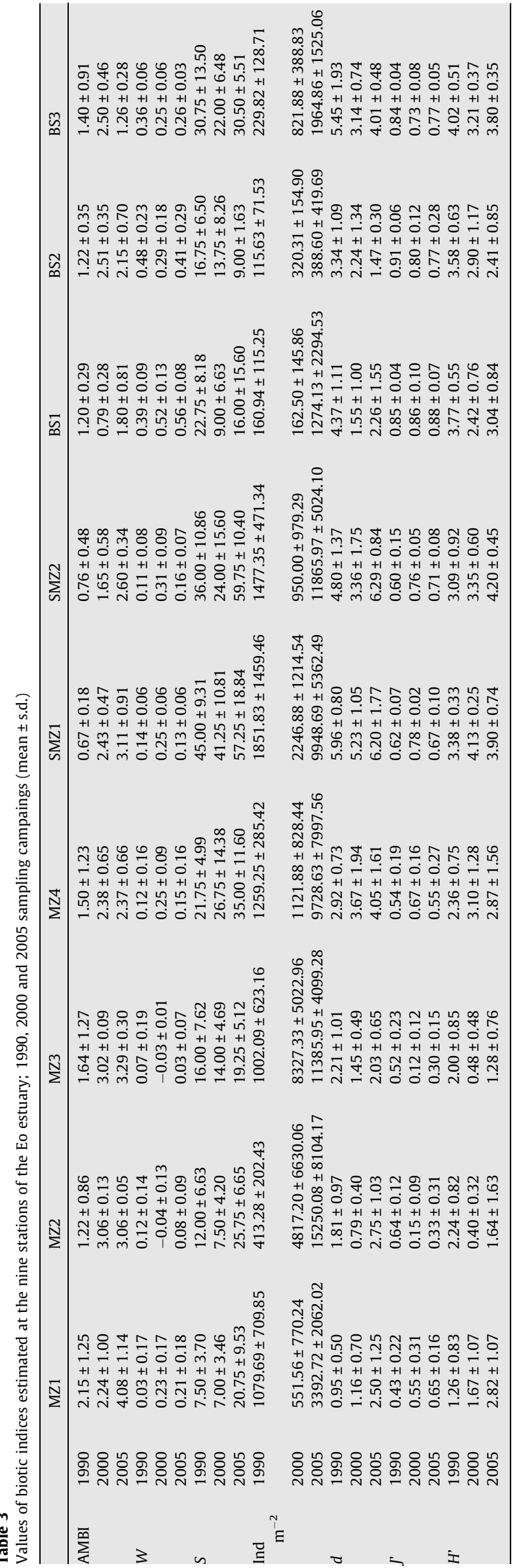

abiotic factors at the broader scale and by biotic factors at finer scales (see review by Snelgrove, 1999). In particular, the distribution and abundance of soft-sediment benthos in natural habitats have been related to the sediment particle size and structure (Seiderer and Newell, 1999; Currie and Small, 2005), and also to the presence and coverage of seagrasses (Boström and Bonsdorff, 1997; Blanchet et al. 2004).

Our results for the Eo estuary are consistent with these findings, elucidating how important sediment grain size and seagrasses beds are in controlling the number of species and the abundance of benthic macro-invertebrates. In fact, as observed in other comparative studies (Edgar et al., 1994; Boström and Bonsdorff, 1997), species richness and abundance were found to be higher in seagrass beds than on the bare sand areas. On the other hand, the Z. marina-Z. noltii mixed meadow (SMZ zone) also presented higher biological diversity than mud flats covered by Z. noltii ( $\mathrm{MZ}$ zone). This is probably related to differences in tidal level and variations in the sediment composition, and also due to differences regarding the structural characteristics of the macrophytes' vegetation (Blanchet et al., 2004). In fact, the SMZ zone is located at a lower tidal level as compared to the MZ zone, and consequently, due to shorter emersion periods, is less constrained in terms of abiotic stress.

Macrobenthic diversity appeared to be negatively correlated with the proportion of fine particles, which was particularly obvious at the Linera inlet. On the other hand, in the sand banks habitat, species diversity decreased from more sheltered (stations BS1, BS2) to more exposed areas (station BS3), demonstrating how diversity can be markedly depressed by sediment instability (Warwick et al., 1990; Cooper et al., 2007). Station BS1, located closer to $Z$. marina meadows presented the highest biological diversity of all stations in the bare sand zone. In fact, the presence of $Z$. marina determines higher sediment stability (Fonseca and

Table 4

Values obtained after the application of a one-way ANOVA test considering the three sampling years

\begin{tabular}{|c|c|c|c|c|}
\hline & $n$ & Mean & $F$ & $p$ \\
\hline \multicolumn{5}{|c|}{ Species richness } \\
\hline 1990 & 36 & 23.1666667 & 5.441 & 0.006 \\
\hline 2000 & 36 & 18.3611111 & & \\
\hline 2005 & 36 & 30.25 & & \\
\hline \multicolumn{5}{|c|}{ Abundance } \\
\hline 1990 & 36 & 989.583333 & 19.442 & $<0.001$ \\
\hline 2000 & 36 & 3499.83472 & & \\
\hline 2005 & 36 & 9078.4475 & & \\
\hline \multicolumn{5}{|c|}{ Margalef } \\
\hline 1990 & 36 & 3.41388889 & 5.093 & 0.008 \\
\hline 2000 & 36 & 2.33944444 & & \\
\hline 2005 & 36 & 3.37055556 & & \\
\hline \multicolumn{5}{|l|}{ Pielou } \\
\hline 1990 & 36 & 0.7 & 2.008 & 0.139 \\
\hline 2000 & 36 & 0.60277778 & & \\
\hline 2005 & 36 & 0.62166667 & & \\
\hline \multicolumn{5}{|c|}{ Shannon-Wiener } \\
\hline 1990 & 36 & 3.02444444 & 3.132 & 0.048 \\
\hline 2000 & 36 & 2.40666667 & & \\
\hline 2005 & 36 & 2.85972222 & & \\
\hline \multicolumn{5}{|c|}{$W$-statistic } \\
\hline 1990 & 36 & 0.295 & 2.021 & 0.138 \\
\hline 2000 & 36 & 0.21138889 & & \\
\hline 2005 & 36 & 0.21027778 & & \\
\hline \multicolumn{5}{|l|}{$A M B I$} \\
\hline 1990 & 36 & 1.31888889 & 23.983 & $<0.001$ \\
\hline 2000 & 36 & 2.27416667 & & \\
\hline 2005 & 36 & 2.64666667 & & \\
\hline
\end{tabular}


Fisher, 1986), and provides important food and refuge supply to neighbour populations (Edgar, 1999).

The different habitats identified and characterized in 1990 remained present in the estuary over 2000 and 2005. Nevertheless, there was a substantial reduction in the area of the Z. noltii-Z. marina mixed meadow during this fifteen years period (from 40 ha in 1990 to 8 ha in 2005), which was associated with the installation of the oyster culture racks in this zone. In fact, just to prepare the racks' installation, seagrasses were physically removed from the bottom. Additionally, green macroalgal blooms (Ulva spp.) have been recorded since 2000 , mainly on mud flats covered by $Z$. noltii, which may constitute a symptom of eutrophication in estuarine environments (Marques et al., 1997, 2003).

From 1990 to 2005, with the exception of station MZ3, the macrobenthic communities showed an increase in number of species and abundance in the areas near the oyster culture racks (zones SMZ and MZ). This was essentially due to the presence of opportunistic, pioneer or tolerant species such as Oligochaeta spp., C. capitata, N. latericius, S. benedicti, P. antennata or H. ulvae, as a function of organic matter enrichment in the system (Pearson and Rosenberg, 1978; Rhoads and Germano, 1982). Moreover, the whole SMZ zone, as well as stations MZ1 and MZ4, exhibited the highest values of biological diversity in 2005. These results suggest that there has been an improvement of macrobenthic communities in these zones in 2005 with respect the reference situation. This type of response to perturbation has been observed in other case studies (e. g. Marques et al. 2003; Patrício et al. 2004), and can be interpreted at the light of the Intermediate Disturbance Hypothesis (IDH) (Connel, 1978).

The $W$-statistic index also suggests an improvement of macrobenthic communities in this area in 2000 in comparison to 1990, which can be mostly explained by the dominance of $B$. reticulatum in 1990, and its absence in 2000. Apparently, the dominance of certain species in the community, small in size although characteristic of non-polluted habitats, may lead to erroneous evaluations when applying this indicator (Salas et al., 2004).

On the contrary, AMBI values revealed some degradation of the macrobenthic communities at the whole SMZ and MZ zones in 2000 and 2005 when compared to 1990, which suggests that this index is more sensitive to intermediate perturbations than diversity measures. This is due to AMBI architecture, since it uses species as indicators of different degrees of organic enrichment (Borja et al., 2000). In this case, the presence of pollution indicator species, classified as tolerant to organic enrichment (group III) or opportunistic (group IV and V) (Borja et al., 2003), was able to capture the system deterioration, although there was an increase in biological diversity and abundance.

Organic enrichment did not notably affect the macrobenthic community on the sand banks area, where interannual changes were minor and species composition remained very similar throughout time. In fact, this zone (mainly stations BS2 and BS3) can be considered as naturally physically disturbed because of sedimentary instability caused by tidal currents and wave action. In this type of environment, soft sediment faunal assemblages typically occupy an early succession stage (Newell et al., 1998; Bolam and Rees, 2003), with dominance of species displaying 'r selected' characteristics. Nevertheless, a certain reduction in biological diversity and biomass, as well as a slight increase in AMBI values from 1990 to 2000, and again to 2005, suggest an increase in the disturbance level. It may be related to an increase in physical disturbance, as the Eo estuary, like other systems from the northern coast of Spain, has been going through a gradual process of in-filling by marine and estuarine deposits (Curras and Mora, 1991). Furthermore, sediment deposition increased after the construction of a new harbour (in 1994) in the western part of the Eo estuary, and an increase of 17 ha in the area of sand banks took place from
1990 to 2005 . Such pressures may partially explain the observed inter-annual variations. In response, there was an increase in abundance of small benthic opportunistic species, such as $S$. squamata, $S$. filicornis and A. latreillei, and a slight reduction in biomass and size of individuals in comparison to 1990.

\subsection{What has been the impact of oyster culture farming?}

Since 1990 the anthropogenic pressure due to oyster culturing in the area has been increasing, and this activity may have become the major driving force behind the organic enrichment observed in the system. In fact, the accumulation of organic matter by bivalve biodeposition is usually the major impact of shellfish farming (Kaiser et al., 1998).

Most of the studies about the effects of bivalve farming were based on post-impact assessment concerning differences in environmental variables from the farm and from adjacent control/reference sites in the same temporal scale (Grant et al., 1995; Crawford et al., 2003; Forrest and Creese, 2006). Some studies revealed significant differences between reference zones and cultivation areas, and eutrophication symptoms were detected in macrobenthic communities beneath farms (Stenton-Dozey et al., 1999; Mirto et al., 2000; Hartstein and Rowden, 2004). However, in other studies, observed effects of shellfish farming were minimal (Grant et al., 1995; Crawford et al., 2003).

In the present study all the sampling stations were located outside of the farms, and the control was temporal, not spatial. We compared the benthic conditions at the study site prior to the start of intensive oyster cultivation (1990), during the installation of the oyster racks (2000), and after some years of shellfish farming (2005). Our results show that (a) changes in the macrobenthic communities at the Linera inlet may be explained by organic enrichment, and (b) such organic enrichment affects not only the area beneath a farm, but also sites located at a certain distance from it.

It has been demonstrated that differences in the extent and magnitude of environmental impacts are likely to depend on farm type (e.g. farm size, culture method, stocking density, and age of the operation) and on the site conditions (e.g. bathymetry and hydrodynamic conditions (Hartstein and Rowden, 2004). Although the oysters stocking densities in the Eo estuary is relatively low compared to other bivalve culture areas (e.g. Grant et al., 1995; Crawford et al., 2003), an important increase in organic matter has been detected in the system. Some studies illustrate that local current patterns are the most important factors influencing the effect of bivalve cultivation on the seabed. Due to dispersion, effects of shellfish biodeposits from farms may be minor in sites that experience high hydrodynamic energy (Hartstein and Rowden, 2004). In the Eo estuary case, shellfish farms are located at the entrance of a shallow sheltered inlet. Oyster biodeposits originating from the racks, combined with a naturally reduced hydrodynamics in that part of the system, can clearly explain the increase in organic matter (Castel et al., 1989). On the other hand, the presence of seagrass beds in this area also favours biodeposition by reducing currents velocity (Fonseca and Fisher, 1986). Besides, Zostera debris also tends to accumulate since they can hardly be transported out of the system.

The supply of organic matter provided by oyster farms may be responsible for the increase in sedimentary organic matter, which has been observed especially in stations closer to the racks (essentially the SMZ zone and MZ4 station). The diversity and richness indices suggest that the increase in organic matter has caused an improvement in macrobenthic communities from the Linera inlet in 2005 with respect the reference situation (1990). Thus, in stations with higher increases in organic matter (essentially the SMZ zone) values of the diversity and richness indices have raised 
significantly. This effect of bivalve culture has been pointed out in other studies (e.g. Grant et al., 1995).

However, the macrobenthic community changes at MZ1, MZ2 and MZ3 stations may be examined further. At MZ1 the diversity indices suggest also an improvement in benthic community, but this station has not been affected by organic enrichment. On the contrary, the sedimentary organic matter content has diminished since 1990. On the other hand, at stations MZ2 and MZ3, although the organic matter increase was lower than in SMZ and MZ4 station, the indices show degradation in macrobenthic communities.

These results show that trends in macrobenthic community changes may depend on its initial conditions. Hence, the more diverse macrobenthic communities inhabiting in $Z$. noltii and $Z$. marina mixed meadows and transitional station MZ4 presented capability to absorb increases in organic matter, and its response was consistent with the IDH, which is thought to be realised in systems with a certain capacity to absorb changing environmental conditions over a larger time scale (Patrício et al., 2004). Instead, the MZ2 and MZ3 stations, from mud flat covered by Z. noltii, responded negatively to the organic enrichment, even though the increase in organic matter observed in this area was minor. Thus, the benthic communities' response to perturbations acting in a system depends in a large extent of its intrinsic buffer capacity.

Changes in macrobenthic communities on different habitats observed since 1990 in the Linera inlet could be interpreted following the approach suggested by Marques et al. (2003) for long time series studies. We assumed the situation in 1990 as an initial status, a kind of climax society with minimal anthropogenic pressure. In 2000, all the indicators suggest an imbalanced situation of the macrobenthic communities, with changes exceeding the expected natural variation. Such a situation seems to reflect a severe perturbation, resulting from an extensive development of shellfish farming, with the installation of many new oyster racks. Physical disturbance was probably the main factor affecting the communities in 2000. In 2005, the macrobenthic community appears more structured again, similar to 1990 , which suggests a recovery, probably as a function of the cessation of new racks installation. Nevertheless, the community did not return to a state similar to that observed in 1990. This suggests that (a) the system might have reached a new state of dynamic equilibrium corresponding to a new specific set of environmental conditions, and (b) the major driving force behind this new state has been the supply of organic matter provided by bivalve farms.

\section{Conclusions and future concerns}

Although the anthropogenic pressure (e.g. oyster racks' implementation, harbour construction) were present throughout the study period in the Eo estuary it was between 1990 and 2000 that the macrobenthic community revealed its worst status. Eutrophication symptoms were visible in the system until 2005, (e.g. increase in biomass of green macroalgae, reduction of Zostera coverage, increase in sedimentary organic matter) but the macrobenthic community showed a higher disorganisation in 2000 followed by an apparent recovery to 2005 .

Results suggested that the additional stimulation of biomass and diversity that may happen as a benthic community responds to anthropogenic induced perturbations (depending on systems' intrinsic buffer capacity), usually referred to as Intermediate disturbance hypothesis (IDH) (Connel, 1978), could describe the developmental pattern found in the system (especially at the $Z$. noltii- $Z$. marina mixed meadows). All the original habitats were still present in 2000 and 2005, but the latest improvements in the benthic quality followed a different direction, rather than a simple return to the original macrobenthic community.
The use of a set of selected indices, rather than a single one, provided an effective approach to analysing the changes. Although indices like the 'Number of Species', 'Margalef' or the 'ShannonWiener' could indicate a status improvement, the values of AMBI revealed a general deterioration in the system in 2000 and 2005 relatively to 1990 , confirming the different direction that the macrobenthic community followed to find a new equilibrium point.

Therefore, to keep shellfish farming at a sustainable level without undesirable impacts, the disturbance intensity must be kept below the system carrying capacity (see for instance McKindsey et al., 2006). This precaution will allow natural communities to cope with pressures, avoiding ecological quality deterioration, which is a key issue in terms of sustainable ecosystem management.

\section{Acknowledgements}

Laura de Paz was supported by a doctoral grant of the Universidad de León. Parts of this work were funded through the Universidad de León project (ULE-AG 85) and the Consejería de Agricultura y Pesca of Principado de Asturias contract. We are grateful to E. Cimas, M., Alonso, M. A., Mayoral and especially J. C. González Ruiz for their help in collecting samples and benthic sorting and to the staff of the Centro de Recursos Pesqueros de Castropol and R. de Paz for logistic support during the field work. The work of the Portuguese team was partially supported in the scope of the project RECONNECT ((PTDC/MAR/64627/2006). We thank the two anonymous reviewers who made a number of valuable comments to improve this manuscript.

\section{References}

Belan, T.A., 2003. Marine environmental quality assessment using polychaete taxocene characteristics in Vancouver Harbour. Marine Environmental Research 57, 89-101.

Blanchet, H., de Montaudouin, X., Lucas, A., Chardy, P., 2004. Heterogeneity of macrozoobenthic assemblages within a Zostera noltii bed: diversity, abundance biomass and structuring factors. Estuarine, Coastal and Shelf Science 61, 111123.

Bolam, S.G., Rees, H.L., 2003. Minimizing impacts of maintenance dredged material disposal in the coastal environment: a habitat approach. Environmental Management 32, 171-188.

Borja, A., Franco, F., Pérez, V., 2000. A marine biotic index to establish the ecological quality of soft-bottom benthos within European estuarine and coastal environments. Marine Pollution Bulletin 40, 1100-1114.

Borja, A., Franco, F., Valencia, V., Bald, J., Muxika, I., Belzunce, M.J., Solaun, O., 2004 Implementation of the European Water Framework Directive from the Basque country (northern Spain): a methodological approach. Marine Pollution Bulletin 48, 209-218.

Borja, A., Muxika, I., Franco, J., 2003. The application of a marine biotic index to different impact sources affecting soft-bottom benthic communities along European coasts. Marine Pollution Bulletin 46, 835-845.

Boström, C., Bonsdorff, E., 1997. Community structure and spatial variation of benthic invertebrates associated with Zostera marina (L.) beds in the northern Baltic Sea. Journal of Sea Research 37, 153-166.

Buchanan, J.B., 1984. Sediment analysis. In: Holme, N.A., McIntyre, A.D. (Eds.) Methods for the Study of Marine Benthos, Blackwell Scientific Publications, Oxford, pp. 41-65.

Carrasco, J.F., Rodríguez, C., 1990. Cultivo de almeja japonesa (Ruditapes philippinarum). Resultados de crecimiento en función del tipo de sustrato y de la altura de marea. En: Landín, A., Cerviño, A. (Eds.), Actas III Congreso Nacional de Acuicultura, 24-27 septiembre, pp. 575-580. Santiago de Compostela, A Coruña, España. Consellría de Pesca, Marisqueo e Acuicultura, Xunta de Galicia. Santiago de Compostela (A Coruña), España.

Castel, J., Labourg, P.J., Escaravage, V., Auby, I., Garcia, M.E., 1989. Influence of seagrass beds and oyster parks on the abundance and biomass patterns of meioand macrobenthos in tidal flats. Estuarine Coastal and Shelf Science 28, 71-85.

Chapman, M.G., Tolhurst, T.J., 2004. The relationship between invertebrate assemblages and bio-dependant properties of sediment in urbanized temperate mangrove forests. Journal of Experimental Marine Biology and Ecology 304, 51-73.

Cigarría, J., Fernández, J.M., López, M., 1995. Viabilidad del cultivo de la ostra plana (Ostrea edulis L.) en la Ría del Eo (Asturias, N España). Iberus 13, 1-8.

Clarke, K.R., 1990. Comparisons of dominance curves. Journal of Experimental Marine Biology and Ecology 138, 143-157. 
Clarke, K.R., Gorley, R.N., 2001. PRIMER v5: User manual/tutorial. Primer-E, Plymouth.

Clarke, K.R., Warwick, R.M., 2001. Change in Marine Communities. An Approach to Statistical Analysis and Interpretation, 2nd edition. Primer-E, Plymouth.

Connel, J., 1978. Diversity in tropical rain forests and coral reefs. Science 199, 13041310.

Cooper, K., Boyd, S., Aldridge, J., Rees, H., 2007. Cumulative impacts of aggregate extraction on seabed macro-invertebrate communities in an area off the east coast of the United Kingdom. Journal of Sea Research 57, 288-302.

Crawford, C., Macleod, C.K.A., Mitchell, I.M., 2003. Qualitative risk assessment of the effects of shellfish farming on the environment in Tasmania, Australia. Ocean \& Coastal Management 46, 47-58.

Curras, A.y., Mora, J., 1991. Comunidades bentónicas de la Ría del Eo (GaliciaAsturias, NW España). Cahiers de Biologie Marine 32, 57-81.

Currie, D.R., Small, K.J., 2005. Macrobenthic community responses to long-term environmental change in an east Australian sub-tropical estuary. Estuarine, Coastal and Shelf Science 63, 315-331.

Diaz, R.J., Rosenberg, R., 1995. Marine benthic hypoxia: a review of its ecological effects and the behavioural responses of benthic macrofauna. Oceanography and Marine Biology. An Annual Review 33, 245-303.

Edgar, G.J., 1999. Experimental analysis of structural versus trophic importance of seagrass beds. I. Effects on macrofaunal and meiofaunal invertebrates. Vie Milieu 49, 239-248.

Edgar, G.J., Shaw, C., Watsona, G.F., Hammond, L.S., 1994. Comparisons of species richness, size-structure and production of benthos in vegetated and unvegetated habitats in Western Port, Victoria. Journal of Experimenta Marine Biology and Ecology 176, 201-226.

Encinar, M.V., Rodríguez, G.F., 1983. Aportaciones para el conocimiento de la dinámica y la sedimentación de la ría del Eo. Asturias-Galicia, NW de España, Cuadernos del Crinas, 5, p. 51.

Everett, R.A., Ruiz, G.M., Carlton, J.T., 1995. Effects of oyster mariculture on submerged aquatic vegetation: An experimental test in a Pacific northwest estuary. Marine Ecology Progress Series 125, 2205-2217.

Fonseca, M.S., Fisher, J.S., 1986. A comparison of canopy friction and sediment movements between four species of seagrass with reference to their ecology and restoration. Marine Ecology Progress Series 29, 15-22.

Forrest, B.M., Creese, R.G., 2006. Benthic impacts of intertidal oyster culture, with consideration of taxonomic sufficiency. Environmental Monitoring and Assessment 112, 159-176.

Frontier, S., 1983. Stratégies d'échantillonage en Écologie. Masson, Paris.

Grant, J., Hatcher, A., Scott, D.B., Pocklington, P., Schafer, C.T., Winters, G.V., 1995. A multidisciplinary approach to evaluating impacts of shellfish aquaculture on benthic communities. Estuaries 18, 124-144.

Gray, J.S., 1974. Animal-sediment relationships. Oceanography and Marine Biology. An Annual Review 12, 223-261.

Guerra, A., Acosta, C., Espinos, F., 1987. Primeras experiencias de cultivo de almeja japonesa (Tapes semidecussatus) y ostra japonesa (Crassostrea gigas) en la ría de Ribadeo (N.W. de España). Cuadernos Marisqueros. Publicaciones Técnicas, 12 pp. 347-352.

Hartstein, N.D., Rowden, A.A., 2004. Effect of biodeposits from mussel culture on macroinvertebrate assemblages at sites of different hydrodynamic regime. Marine Environmental Research 57, 339-357.

Hill, A.S., Veale, L.O., Pennington, D., Whyte, S.G., Brand, A.R., Hartnoll, R.G., 1999 Changes in Irish Sea Benthos: Possible effects of 40 years of dedging. Estuarine Coastal and Shelf Science 48, 739-750.

Junoy, J., Viéitez, J.M., 1990. Macrozoobenthic community structure in the Ría de Foz, an intertidal estuary (Galicia, Northwest Spain). Marine Biology 107, 329339.

Kaiser, M.J., Laing, I., Utting, S.D., Burnell, G.M., 1998. Environmental impacts of bivalve mariculture. Journal of Shellfish Research 17, 59-66.

Laborda, A.J., Cimas, E., 1991. Cartografía de los sedimentos superficiales de la Ría del Eo, Asturias. VII Simposio Ibérico de Estudios del Bentos Marino.

Laborda, A.J., 1995. Informe ambiental de la Ría del Eo. Conserjería de Pesca y Ordenación del Territorio. Principado de Asturias. Unpublished report.

Laborda, A.J., Cimadevilla, I., Capdevilla, L.y., García, J.R., 1997. Distribución de las praderas de Zostera noltii Hornem., 1832 en el litoral del norte de España. Publicaciones Especiales. Instituto Español de Oceanografía 23, 273-282.
Llansó, R.J., 1992. Effects of hypoxia on estuarine benthos: the lower Rappahannock River (Chesapeake Bay), a case study. Estuarine, Coastal and Shelf Science 35, 491-515.

Marques, J.C., Nielsen, S.N., Pardal, M.A., Jorgensen, S.E., 2003. Impact of eutrophication and river management within a framework of ecosystem theories. Ecological Modelling 166, 147-168.

Marques, J.C., Pardal, M.A., Nielsen, S.N., Jorgensen, S.E., 1997. Analysis of the properties of energy and biodiversity along an estuarine gradient of eutrophication. Ecological Modelling 102, 155-167.

McKindsey, C.W., Thetmeyer, T., Landry, T., Silver, W., 2006. Review of recent carrying capacity models for bivalve culture and recommendations for research and management. Aquaculture 261, 451-462.

Mirto, S., La Rosa, T., Danovaro, R., Mazzola, A., 2000. Microbial and Meifaunal response to intensive mussel-farm bideposition in coastal sediments of the Western Mediterranean. Marine Pollution Bulletin 40, 244-252.

Morrisey, D.J., Howitt, L., Underwood, A.J., Stark, J.S., 1992a. Spatial variation in softsediment benthos. Marine Ecology Progress Series 81, 197-204.

Morrisey, D.J., Underwood, A.J., Howitt, L., Stark, J.S., 1992b. Temporal variation in soft-sediment benthos. Journal of Experimental Marine Biology and Ecology $164,233-245$.

Newell, R.C., Seiderer, L.J., Hitchcock, D.R., 1998. The impact of dredging works in coastal waters: a review of the sensitivity to disturbance and subsequent recovery of biological resources on the sea bed. Oceanography and Marine Biology. An Annual Review 36, 127-178.

Ottmann, F., Sornin, J.M., 1982. Relationship between marine bottom elevation and various types of marine culture. Atlantica 5, 88-89.

Patrício, J., Ulanowicz, R., Pardal, M.A., Marques, J.C., 2004. Ascendency as an ecological indicator: a case study of estuarine pulse eutrophication. Estuarine, Coastal and Shelf Science 60, 23-35.

Pearson, T.H., Rosenberg, R., 1978. Macrobenthic succession in relation to organic enrichment and pollution of the marine environment. Oceanography and Marine Biology. An Annual Review 16, 229-231.

Rakocinski, C.F., Brown, S.S., Gaston, G.R., Heard, R.W., Walker, W.W., Summers, J.K. 1997. Macrobenthic responses to natural and contaminant-related gradients in Northern Gulf of Mexico Estuaries. Ecological Applications 7, 1278-1298.

Reiss, H., Kroncke, I., 2005. Seasonal variability of benthic indices: An approach to test the applicability of different indices for ecosystem quality assessment. Marine Pollution Bulletin 50, 1490-1499.

Rhoads, D.C., Germano, J.D., 1982. Characterization of organism-sediment relations using sediment profile imaging - an efficient Method of Remote Ecological Monitoring of the Seafloor (Remots TM System). Marine Ecology Progress Series $8,115-128$.

Salas, F., Neto, J.M., Borja, A., Marques, J.C., 2004. Evaluation of the applicability of a marine biotic index to characterize the status of estuarine ecosystems: the case of Mondego estuary (Portugal). Ecological Indicators 4, 215-225.

Sanders, H.L., Mangelsdorf, P.C., Hampson, G.R., 1965. Salinity and faunal distribution in the Pocasset River, Massachusetts. Limnology and Oceanography $10,216-229$.

Seiderer, L.J., Newell, R.C., 1999. Analysis of the relationship between sediment composition and benthic community structure in coastal deposits: Implications for marine aggregate dredging. ICES Journal of Marine Science 56, 757-765.

Snelgrove, P.V.R., 1999. Getting to the bottom of marine biodiversity: sedimentary habitats. Bioscience 49, 129-138.

Stenton-Dozey, J.M., Jackson, L.F., Busby, J., 1999. Impact of mussel culture on macrobenthic community structure in Saldanha Bay, South Africa. Marine Pollution Bulletin 39, 357-366.

Warwick, R.M., Platt, H.M., Clarke, K.R., Agard, J., Gobin, J., 1990. Analysis of macrobenthic and meiobenthic community structure in relation to pollution and disturbance in Hamilton Harbour, Bermuda. Journal of Experimental Marine Biology and Ecology 138, 119-142.

Warwick, R.M., Uncles, R.J., 1980. Distribution of benthic macrofauna associations in the Bristol Channel in relation to tidal stress. Marine Ecology Progress Series 3, 97-103.

Warwick, R.M., 1986. A new method for detecting pollution effects on marine macrobenthic communities. Marine Biology 92, 557-562.

Wilson, W.H., 1991. Competition and predation in marine soft-sediment communities. Annual Review of Ecology and Systematics 21, 221-241. 